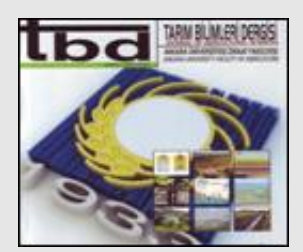

Tarım Bilimleri Dergisi

Journal of Agricultural Sciences

Tar. Bil. Der.

Dergi web sayfası:

www.agri.ankara.edu.tr/dergi

Journal homepage:

www.agri.ankara.edu.tr/journal

\title{
A Multivariate Analysis in Relation to Edaphic and Environmental Factors of Rangelands Vegetation of Mugla Province
}

\author{
Mehmet OTEN ${ }^{\mathrm{a}}$, Cengiz ERDURMUS ${ }^{\mathrm{a}}$, Semiha KIREMITCI ${ }^{\mathrm{a}}$, Mustafa SOYSAL ${ }^{\mathrm{a}}$, Mustafa AVCI $^{\mathrm{b}}$, Celal $\mathrm{YUCEL}^{\mathrm{c}}$, \\ Ilker INAL ${ }^{d}$, Onder KABAS ${ }^{\text {, }}$, Mustafa SURMEN ${ }^{\mathbf{f}}$

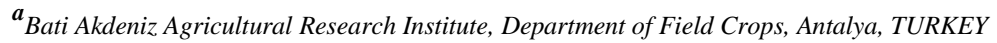

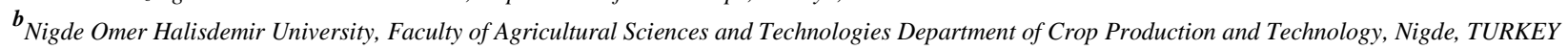

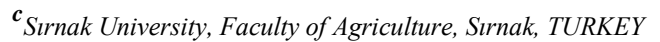 \\ ${ }^{d}$ Dogu Akdeniz Agricultural Research Institute, Department of Field Crops, Adana, TURKEY

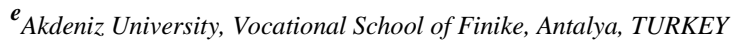

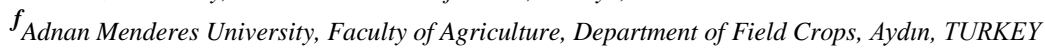

\section{ARTICLE INFO}

Research Article

Corresponding Author: Mehmet OTEN, E-mail: moten07@ hotmail.com, Tel: +90 (532) 5681307

Received: 05 February 2019, Received in Revised Form: 28 March 2019, Accepted: 31 March 2019

\section{AUTHORS ORCID ID:}

(Mehmet OTEN: 0000-0001-8299-2805), (Cengiz ERDURMUS: 0000-0002-2185-9901), (Semiha KIREMITCI: 0000-0001-5533-0849), (Mustafa SOYSAL: 0000-0002-1158-9071), (Mustafa AVCI: 0000-0003-0875-511X), (Celal YUCEL: 0000-0001-6792-5890), (Ilker INAL: 0000-0002-5891-8004), (Onder KABAS: 0000-0003-0703-4804), (Mustafa SURMEN: 0000-0001-9748-618X)

\section{ABSTRACT}

This study was carried out in order to compare in 20 different rangeland sample areas that determined in order to environmental variables, vegetation and soil properties by multivariate ordination analysis in Mugla province. Cluster analysis was made to determine the similarity and species compositions of sample areas, and as a result of this analysis, three different groups have occurred. Additionally, detrended correspondence analysis (DCA) was made after the indicator species analysis. The interaction between environmental and soil-borne factors as altitude, distance to village, soil depth, $\mathrm{pH}$ in saturated soil with water, lime and surface stoniness were found to be significant and this significance was expressed by graphs. Moreover, it was indicated that relationship with species in the vegetation of the variables that were determined as significant by tables and figures. The relationship with the species in the vegetation of the variables that were determined as significant was also indicated. The result of the study showed that environmental variables as soil depth, soil $\mathrm{pH}$ saturated with water, stony surface, altitude and distance to villages had a significant effect on the species diversity and distribution in the samples areas.

Keywords: Clustering analysis; Multivariate analysis; Rangeland

C Ankara Üniversitesi Ziraat Fakültesi

\section{Introduction}

The best way to learn about habitat, niche, and vegetation beside the different interaction between plants in an ecosystem is an investigation of plant biodiversity (Khan et al 2016). Biodiversity is defined as species richness that consisting of the influence of different environmental characters (Khan et al 2018). It is important that examination of the relationship between environmental factors and plants in these ecosystems for better understanding and management rangeland ecosystems, which are among the areas with the richest vegetative biodiversity in the world. The impact of environmental factors on plant communities has been the subject of many ecological studies in recent years (Amiri \& Saadatfar 2009; Altin et al 2011; Ispirli et al 2016). Determination of the interaction between different biotic and abiotic components of an ecosystem is an important part of ecological studies (Rahman et al 2016; Khan et al 2017). The species composition, which is one of the main components of rangeland ecosystems, is highly controlled by environmental factors. Climate, 
topography, and soil characteristics are the main environmental factors (Hoveizeh 1997; Clark \& Mann 1999; Escudero et al 2000; Solon et al 2007; Altın et al 2011; Surmen \& Kara 2018). When the relationship between environmental factors and vegetation is investigated, it is thought that the location of plants is not a coincidence. Therefore, researchers investigate various factors (Abiotic and Biotic) that interact in the formation of plant community structure. These factors contribute to understanding the distribution, composition, and diversity of plant species and communities (Brown 1984). It is difficult to state which factors actually cause changes in vegetation when a large number of environmental factors are extremely effective (Partridge \& Wilson 1989). Researchers have stated that each of the ecological factors had many effects on plant distribution (Clark \& Mann 1999). The most important factors that cause the vegetation to dissipate due to the soil characteristics of different species in ecosystems are topographic parameters such as slope and aspect. Additionally, variations in the composition of the plant species throughout the altitude and latitude are one of the most effective environmental variables in the classification of plant species in these regions (Kitayama 1992; Altin et al 2011). Quantitative classification and ordination analysis methods are used to understand the basic relationship between environmental characteristics and plant communities. These methods help to identify ecological similarities between different vegetations and finding the environmental factors that are important in ecological structure determination (Zhang et al 2006; Amiri \& Saadatfar 2009). Scientists, who are interested in ecology, use a multivariate approach to investigate and summarize the ecological data set related to environmental variables. Statistical analysis of these data helps to find the actual position of plant species in rangelands (Curtis \& McIntosh 1950). Multivariate analysis methods are commonly used to qualitative and quantitative relationships with botanical composition and environmental factors (Villers-Ruiz et al 2003; Kargar-Chigani et al 2017). One of these methods, the ordination analysis, is a commonly used method to study the vegetation-environment relationships (Jin-Tun \& Oxley 1994; Siefert et al 2012). Multivariate statistical analytical programs contribute to ecologists to analyze the effects of environmental variables on all species and to know the structure in the data set (Anderson et al 2006). Mugla province, where the study was conducted, is located in the southwestern of Turkey, has rich biotope and biota, endemic species, and it is one of the few provinces in terms of natural resources and environmental-conservation areas. For this reason, the effects of different environmental variables on rangeland botanical composition were investigated by multivariate analysis methods in 20 different sample areas in Mugla province that has rich biodiversity.

\section{Material and Methods}

The experiment was carried out in 20 different rangeland areas within the borders of Mugla province. The general characteristics of environmental factors that are important in the ordination analysis are given in Table 1 . In the vegetation study, wheel point method (Gokkus et al 1995) and adapted loop method were used (Koc \& Cakal 2004). In this study; soil texture properties were determined according to the hydrometer method by Gee \& Bauder (1986), $\mathrm{pH}$-saturated soil in the water was determined according to the $\mathrm{pH}$ meter method by McLean (1982), $\mathrm{CaCO}_{3}$ content was determined that according to the Scheibler calcimeter by Nelson \& Sommers (1982), soil $\mathrm{P}_{2} \mathrm{O}_{5}$ content was determined that according to the molybdosophosphoric blue color method by Olsen \& Sommers (1982), the $\mathrm{K}_{2} \mathrm{O}$ content was determined that according to the flame photometry by Thomas (1982) and the organic matter content was determined that according to the Smith-Weldon method (Nelson \& Sommers 1982). In the result of the vegetation study, 116 species in 20 sample areas were determined, however, the species which were below $5 \%$ frequency according to coverage ratio were removed before analysis (Table 2). Cluster analysis was performed to determine the similarity characteristics of the sample areas using the PC-ORD package program in the study. Before the analysis, the remaining 5\% of the species detected in the sample areas were eliminated and the analysis was continued with the remaining species. The Cluster Euclidean Ward's method was used for the analysis and distinction groups were determined by MRPP (Multi-Response Permutation Procedures) test (McCune \& Mefford 1999). After the separation groups, DCA was preferred for ordination analysis (Hill \& Gauch 1980). 
Table 1- General characteristics of pasture areas that are important in the ordinate analysis in 20 different pasture areas of Mugla Province

\begin{tabular}{|c|c|c|c|c|c|c|c|c|c|c|c|}
\hline Locations & $\underset{\substack{\mathbb{Z} \\
\stackrel{\mathbb{Z}}{\mathbb{Z}}}}{ }$ & $\begin{array}{c}\text { pH in } \\
\text { soil } \\
\text { saturated } \\
\text { with } \\
\text { water } \\
\end{array}$ & $\begin{array}{c}\text { Lime } \\
(\%)\end{array}$ & $\begin{array}{c}\text { Distance } \\
\text { to the } \\
\text { Village } \\
(\mathrm{km})\end{array}$ & 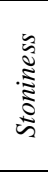 & 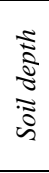 & County & Village & Site & Latitude & Longitude \\
\hline MUG001 & 1384 & 6.10 & 0.72 & 5.0 & 1 & 4 & Seydikemer & & Seki & $35 \mathrm{~S} 0741063$ & UTM4079330 \\
\hline MUG002 & 1420 & 5.94 & 0.72 & 5.0 & 2 & 3 & Seydikemer & & Seki & $35 \mathrm{~S} 0741213$ & UTM4079257 \\
\hline MUG003 & 2 & 6.40 & 0.97 & 2.0 & 4 & 2 & Bodrum & & Kudur & $36 \mathrm{~S} 0648581$ & UTM3018040 \\
\hline MUG004 & 9 & 6.71 & 1.08 & 2.0 & 2 & 3 & Ortaca & & Tepearası & $35 \mathrm{~S} 0648780$ & UTM4082848 \\
\hline MUG005 & 10 & 7.43 & 0.97 & 2.0 & 1 & 4 & Koycegiz & Donusbeleni & Donusbeleni & $35 \mathrm{~S} 0641815$ & UTM4095054 \\
\hline MUG006 & 17 & 7.97 & 17.58 & 2.5 & 1 & 4 & Ortaca & & Tepearası & $35 \mathrm{~S} 0649092$ & UTM4083032 \\
\hline MUG007 & 12 & 5.46 & 0.84 & 1.0 & 1 & 4 & Milas & & Koru & $35 \mathrm{~S} 0563867$ & UTM4122029 \\
\hline MUG008 & 20 & 7.57 & 11.59 & 2.0 & 1 & 4 & Ortaca & Tepearası & Tepearası & $35 \mathrm{~S} 0648947$ & UTM4083120 \\
\hline MUG009 & 6 & 7.39 & 7.10 & 1.0 & 1 & 4 & Milas & Gurcamlar & Alagun & $35 \mathrm{~S} 0544972$ & UTM4126429 \\
\hline MUG010 & 13 & 6.82 & 1.04 & 1.0 & 1 & 4 & Ortaca & Ortakoy & Tepearası & $35 \mathrm{~S} 0649005$ & UTM4083015 \\
\hline MUG011 & 10 & 7.43 & 8.72 & 1.0 & 1 & 4 & Milas & & Koru & $35 \mathrm{~S} 0563635$ & UTM4122702 \\
\hline MUG012 & 1400 & 5.61 & 0.07 & 5.0 & 1 & 3 & Seydikemer & Seki & Seki & $35 \mathrm{~S} 0741086$ & UTM4079742 \\
\hline MUG013 & 9 & 6.89 & 0.91 & 1.0 & 4 & 4 & Milas & & Koru & $35 \mathrm{~S} 0563565$ & UTM4122805 \\
\hline MUG014 & 12 & 7.61 & 10.91 & 1.0 & 4 & 2 & Milas & Gurcamlar & Alagun & $35 \mathrm{~S} 0544824$ & UTM4126451 \\
\hline MUG015 & 9 & 7.98 & 13.45 & 1.0 & 4 & 4 & Milas & & Koru & $35 \mathrm{~S} 0563565$ & UTM4122805 \\
\hline MUG016 & 9 & 7.36 & 1.29 & 2.0 & 4 & 4 & Koycegiz & Donusbeleni & Donusbeleni & $35 \mathrm{~S} 0641716$ & UTM4094888 \\
\hline MUG017 & 0 & 6.16 & 1.11 & 2.0 & 3 & 2 & Bodrum & Kudur & Yalıkavak & $35 \mathrm{~S} 0523593$ & UTM4108970 \\
\hline MUG018 & 14 & 7.35 & 30.17 & 1.0 & 1 & 2 & Milas & Gurcamlar & Gurcamlar & $35 \mathrm{~S} 0544989$ & UTM4126614 \\
\hline MUG019 & 12 & 5.48 & 0.91 & 1.0 & 1 & 3 & Milas & & Koru & $35 \mathrm{~S} 0563737$ & UTM4122000 \\
\hline MUG020 & 30 & 8.07 & 13.45 & 2.0 & 3 & 2 & Ortaca & Ortakoy & Ortakoy & $35 \mathrm{~S} 0648668$ & UTM4082804 \\
\hline
\end{tabular}


Table 2- Correlation values of Detrended Correspondence Analysis (DCA) depending on the species of matrix axis

\begin{tabular}{|c|c|c|c|c|c|c|c|c|c|}
\hline \multirow{2}{*}{$\begin{array}{l}\text { Axis } \\
\text { Species }\end{array}$} & \multicolumn{3}{|c|}{1} & \multicolumn{3}{|c|}{2} & \multicolumn{3}{|c|}{3} \\
\hline & $\mathrm{r}$ & r-sq & tau & $r$ & $r-s q$ & tau & $r$ & $r-s q$ & tau \\
\hline Aegilops neglecta & -0.384 & 0.147 & -0.069 & 0.536 & 0.287 & 0.382 & -0.149 & 0.022 & -0.260 \\
\hline Avena sativa & -0.017 & 0.000 & -0.030 & 0.516 & 0.266 & 0.500 & -0.123 & 0.015 & -0.114 \\
\hline Bromus danthoniae & -0.558 & 0.312 & -0.562 & -0.275 & 0.075 & -0.069 & 0.096 & 0.009 & -0.082 \\
\hline Bromus tectorum & 0.177 & 0.031 & 0.307 & -0.199 & 0.039 & -0.244 & -0.073 & 0.005 & -0.244 \\
\hline Cantaurea iberica & 0.041 & 0.002 & -0.036 & 0.239 & 0.057 & 0.226 & -0.184 & 0.034 & -0.139 \\
\hline $\begin{array}{l}\text { Cardopatium } \\
\text { corymbosum }\end{array}$ & 0.193 & 0.037 & 0.168 & 0.355 & 0.126 & 0.343 & 0.102 & 0.010 & 0.139 \\
\hline Carex acuta & -0.175 & 0.031 & -0.065 & 0.217 & 0.047 & 0.182 & 0.025 & 0.001 & 0.000 \\
\hline Carex atrata & 0.466 & 0.218 & 0.434 & -0.156 & 0.024 & -0.217 & 0.606 & 0.368 & 0.375 \\
\hline Cynodon dactylon & 0.356 & 0.127 & 0.251 & -0.110 & 0.012 & -0.195 & 0.622 & 0.387 & 0.463 \\
\hline Festuca ovina & 0.718 & 0.516 & 0.560 & 0.301 & 0.091 & 0.248 & -0.337 & 0.114 & -0.248 \\
\hline Hordeum bulbosum & 0.087 & 0.008 & -0.006 & 0.417 & 0.174 & 0.536 & -0.145 & 0.021 & -0.211 \\
\hline Hordeum marinum & 0.190 & 0.036 & 0.206 & -0.089 & 0.008 & -0.039 & 0.366 & 0.134 & 0.318 \\
\hline Juncus acutus & 0.291 & 0.085 & 0.302 & 0.287 & 0.082 & 0.315 & 0.153 & 0.023 & 0.178 \\
\hline Lolium multiflorum & -0.383 & 0.147 & -0.314 & -0.560 & 0.313 & -0.284 & -0.103 & 0.011 & -0.080 \\
\hline Lolium perenne & -0.539 & 0.291 & -0.386 & -0.361 & 0.131 & -0.168 & 0.206 & 0.043 & 0.314 \\
\hline Notobasis syriaca & 0.073 & 0.005 & 0.134 & 0.004 & 0.000 & 0.134 & -0.065 & 0.004 & -0.055 \\
\hline Pistacia terebinthus & -0.324 & 0.105 & -0.276 & -0.693 & 0.480 & -0.474 & -0.452 & 0.204 & -0.375 \\
\hline Plantago atrata & -0.189 & 0.036 & -0.143 & 0.271 & 0.073 & 0.195 & 0.224 & 0.050 & 0.235 \\
\hline Poa bulbosa & 0.628 & 0.395 & 0.494 & 0.059 & 0.003 & -0.020 & -0.297 & 0.088 & -0.276 \\
\hline $\begin{array}{l}\text { Polypogon } \\
\text { monspeliensis }\end{array}$ & -0.422 & 0.178 & -0.194 & -0.212 & 0.045 & -0.081 & 0.302 & 0.091 & 0.293 \\
\hline Trifolium campestre & 0.634 & 0.402 & 0.261 & -0.075 & 0.006 & -0.274 & -0.281 & 0.079 & -0.117 \\
\hline Trifolium hirtum & -0.284 & 0.081 & -0.178 & 0.105 & 0.011 & 0.138 & 0.096 & 0.009 & 0.020 \\
\hline
\end{tabular}

\section{Results and Discussion}

According to the results of cluster analysis, similar 3 groups occurred. Among these groups, the first group consisted of MUG001, MUG012, MUG005, MUG016, second group consisted of MUG003, MUG013, MUG017, MUG018, MUG004, MUG020, MUG014, MUG006, MUG010 and third group consisted of MUG007, MUG009, MUG011, MUG015, MUG008, MUG019 (Figure 1). Indicator species in segregation groups were determined by indicator species analysis in PC-ORD program. According to the results of the indicator species analysis, Carex atrata (60.0), Poa bulbosa 
(60.0) and Trifolium campestre (73.1) were the indicator species of the first group, while Bromus danthoniae (57.9) was the inductor species of the second group and finally, the indicators of the third group were Avena sativa, Cardopatium corymbosum, Hordeum bulbosum (70.7), Juncus acutus (87.4), Notobasis syriaca (57.5). After Multi-Response Permutation Procedures (MRPP) analysis, detrended correspondence analysis was preferred for the ordination analysis and the correlation of both variables with the axes was calculated (Tables 3-4). As a result of the analysis, it was found that $1^{\text {st }}$ axis explanation of the percentage $0.54110,2^{\text {nd }}$ axis explanation of the percentage of 0.37308 and $3^{\text {rd }}$ axis explanation 0.14921 (Table 4). When the correlation between vegetation data matrix and environmental data matrix was investigated, it was seen that environmental variables such as $\mathrm{pH}$ in water-saturated soil, lime, surface stoniness, altitude, usable potassium, distance to village, soil depth are important. It is seen that the species of Bromus tectorum, Cardopitum corymbesum, Carex atrata, Cynodon dactylon, Festuca ovina, Juncus acutus, Poa bulbosa, and Trifolium campestre have an increase and growth potential with increasing elevation, distance to village and soil depth variables. Among these characteristics, the correlation between altitude $(\mathrm{r}=0.624)$ and Festuca ovina $(\mathrm{r}=0.718)$, Poa bulbosa $(\mathrm{r}=0.628)$ and Trifolium campestre $(\mathrm{r}=0.634)$ was determined as the closest positive relationship. Furthermore, the species that the highest negative relationship with altitude was determined as Bromus danthoniae $(\mathrm{r}=-0.558)$ and Lolium perenne $(\mathrm{r}=-$ 0.539). Carex atrata $(\mathrm{r}=0.466)$ was observed that closest positive relationship with village distance $(\mathrm{r}=0.541)$ and soil depth $(\mathrm{r}=0.532)$ variables. Considering other variables; when $\mathrm{pH}$ in saturated with water, lime and surface stoniness increase Aegilops neclecta, Bromus danthoniae, Lolium multiflorum, Lolium perenne, Pistacia terebinthus, Polygonum monspeliensis, and Trifolium hirtum species also show an increase. While lime variable parameter was significantly positive correlated to negative position with Aegilops neclecta $(\mathrm{r}=-0.384)$, Bromus danthoniae $(\mathrm{r}=-0.558)$, Lolium multiflorum $(\mathrm{r}=-0.383)$, Lolium perenne $(\mathrm{r}=-0.539)$ and Polygonum monspeliensis $(\mathrm{r}=-0.422)$ species, $\mathrm{pH}$ in saturated with water $(\mathrm{r}=-0.350)$ parameter significantly positive correlated to negative position with Aegilops neclecta $(\mathrm{r}=-0.384)$, Lolium multiflorum $(\mathrm{r}=-0.383)$ and Pistacia terebinthus $(\mathrm{r}=-0.324)$ species. It was observed that surface stoniness $(\mathrm{r}=-$ 0.241 ) and Trifolium hirtum ( $\mathrm{r}=-0.284$ ) showed the highest positive correlation (Tables 3-4, Figure 2). When the groups were examined together, while the altitude, distance to village and depth of soil were determined as a high in the sample areas belonging to the first group, soil depth was found to be high in the second group of sample areas. Finally, in the third group in the sample areas, the $\mathrm{pH}$ in the water-saturated soil, lime and surface stoniness variables were found to be high (Figure 3). According to the results, it was observed that soil factors were closely related to vegetation. It has been determined that soil factors with soil chemistry changes have positive or negative effects on the species in vegetation. Similar results were reported by other researchers (Kumar 1996; Ridolfi et al 2008; Amiri \& Saadatfar 2009; Kabir et al 2010; Kirkpatrick et al 2014). It has been determined that different species have different effects depending on the change in altitude, which is one of the environmental factors and has a close relationship with vegetation change. This result was in accordance with Ispirli et al (2016). Many researchers also have investigated the effects of environmental factors on vegetation change (Zhang \& Dong 2009; Mofidi et al 2012; Surmen et al 2013; Zhengchao et al 2016).

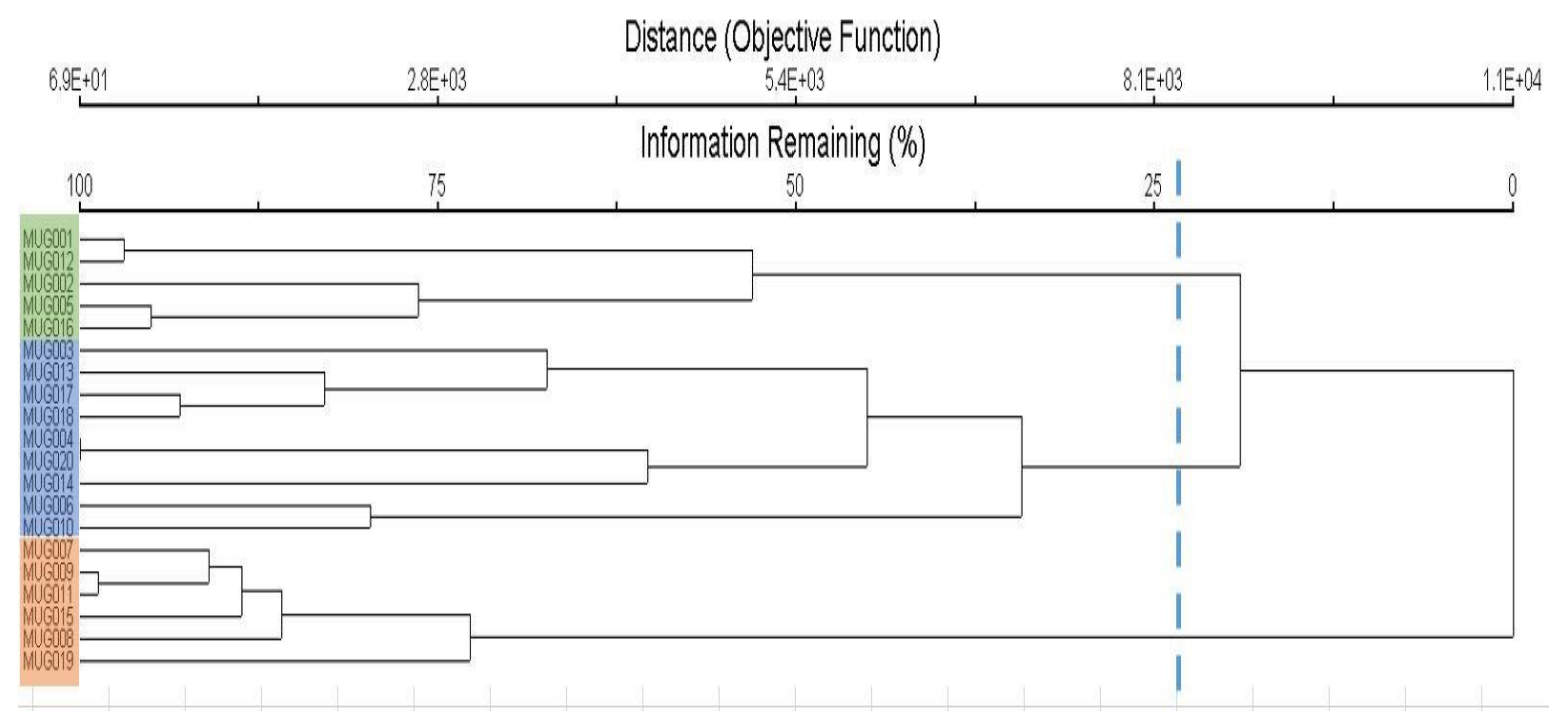

Figure 1- Dendrogram obtained by hierarchical cluster analysis of 20 samples areas 


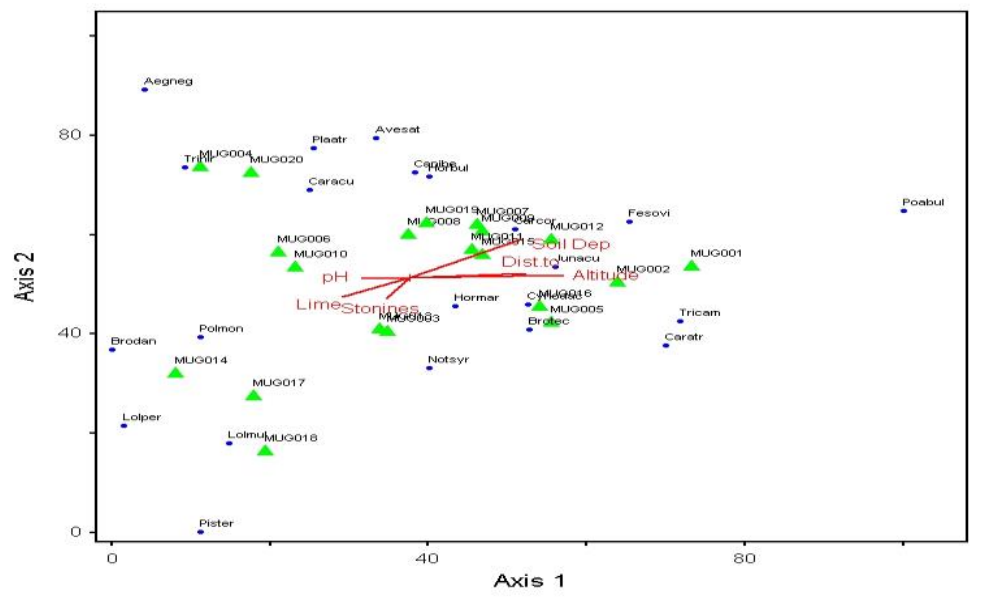

Figure 2- Ordinate distribution according to Detrended Correspondence Analysis (DCA) influenced by environmental factors in species detected in 20 sample areas

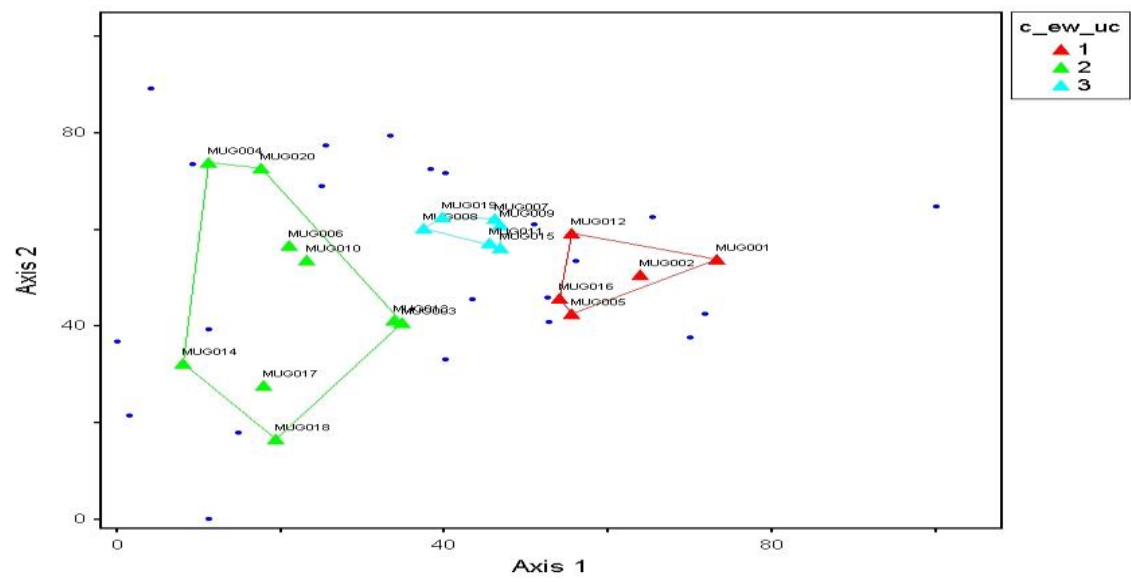

Figure 3- Group distribution of 20 sample areas by Cluster Euklidien Ward's in Detrended Correspondence Analysis (DCA)

Table 3- Correlation values of Detrended Correspondence Analysis (DCA) depending on the environmental data of matrix axis

\begin{tabular}{lccccccccc}
\hline Axis & \multicolumn{3}{c}{$l$} & \multicolumn{2}{c}{2} & \multicolumn{3}{c}{3} \\
\hline Soil properties in pastures & $r$ & $r-s q$ & tau & $r$ & $r$-sq & tau & $r$ & $r$-sq & tau \\
\hline Altitude & 0.624 & 0.389 & 0.108 & 0.100 & 0.010 & 0.162 & -0.358 & 0.128 & -0.184 \\
pH in soil saturated with water & -0.350 & 0.123 & -0.206 & -0.049 & 0.002 & -0.037 & 0.363 & 0.131 & 0.237 \\
Lime & -0.414 & 0.172 & -0.415 & -0.274 & 0.075 & -0.053 & -0.092 & 0.008 & 0.128 \\
Total salt & 0.073 & 0.005 & -0.016 & -0.188 & 0.035 & -0.144 & 0.670 & 0.449 & 0.485 \\
EC & -0.051 & 0.003 & -0.032 & -0.228 & 0.052 & -0.189 & 0.570 & 0.325 & 0.432 \\
Plant-available potassium & 0.234 & 0.055 & 0.175 & 0.176 & 0.031 & 0.027 & -0.152 & 0.023 & -0.111 \\
Organic matter & -0.023 & 0.001 & 0.016 & -0.045 & 0.002 & 0.005 & 0.168 & 0.028 & 0.132 \\
Erodibilite & -0.073 & 0.005 & -0.105 & -0.045 & 0.002 & -0.082 & -0.390 & 0.152 & -0.269 \\
Hydraulic conductivity & -0.011 & 0.000 & 0.053 & -0.091 & 0.008 & -0.021 & -0.021 & 0.000 & -0.074 \\
Field capacity & -0.011 & 0.000 & -0.011 & 0.016 & 0.000 & 0.063 & 0.309 & 0.096 & 0.242 \\
Permenent wilting & -0.079 & 0.006 & -0.032 & -0.041 & 0.002 & 0.063 & 0.336 & 0.113 & 0.242 \\
Bulk density & 0.002 & 0.000 & 0.048 & -0.030 & 0.001 & -0.069 & -0.192 & 0.037 & -0.143 \\
Distance to village & 0.541 & 0.293 & 0.242 & 0.134 & 0.018 & 0.038 & -0.222 & 0.049 & -0.064 \\
Slope & -0.146 & 0.021 & -0.130 & 0.081 & 0.007 & -0.020 & -0.241 & 0.058 & -0.266 \\
Erosion & -0.148 & 0.022 & -0.218 & 0.099 & 0.010 & 0.008 & -0.071 & 0.005 & -0.121 \\
Stoniness & -0.241 & 0.058 & -0.216 & -0.288 & 0.083 & -0.268 & 0.076 & 0.006 & 0.164 \\
Soil depth & 0.532 & 0.283 & 0.392 & 0.388 & 0.151 & 0.166 & 0.106 & 0.011 & 0.126 \\
\hline
\end{tabular}

Journal of Agricultural Sciences (Tarım Bilimleri Dergisi) 26 (2020) 254-262 
Table 4- The results of the length and eigenvalues in Detrended Correspondence Analysis (DCA)

\begin{tabular}{llll}
\hline & Axis 1 & Axis 2 & Axis 3 \\
\cline { 2 - 4 } Eigen value & 0.54110 & 0.37308 & 0.14921 \\
Gradient length & 3.473 & 2.975 & 2.923 \\
\hline
\end{tabular}

\section{Conclusions}

Rangeland areas have had a great impact on every period of human history from ancient times to the present day. For the suitable management of rangeland areas that have biodiversity and supply the nutritional needs of livestock, it is very important to know the species of plants in the area and investigate their relationship with environmental factors. For this purpose, the species and environmental variables were examined by vegetation study in 20 different sample areas by ordination analysis, especially in Mugla province, where is located in a known ecology with its rich in biodiversity. According to the results, it was determined that many environmental variables had an effect on botanical species composition. The results of the study revealed the species that have a growing potential in the regions. The data obtained from this study will be a resource for future studies about rangeland management and improvement in these areas.

\section{Acknowledgements}

This study was funded by General Directorate of Agricultural Research And Policies (TAGEM) and General Directorate of Plant Production (BUGEM) of Republic of Turkey Ministry of Agriculture and Forestry, furthermore, thank you for the lecturers who organized the scientific activity by 1059B291500384 Project that funded by TUBITAK-2229 Scientific Human Resource Support Program.

\begin{tabular}{|ll|}
\hline Abbreviations and Symbols \\
\hline DCA & Detrended Correspondence Analysis \\
MRPP & Multi-Response Permutation Procedures \\
TAGEM & General Directorate of Agricultural Research and Policies \\
BUGEM & General Directorate of Plant Production \\
TUBITAK & The Scientific and Technological Research Council of Turkey \\
MUG & Mugla Province \\
$p H$ & Stands for the potential of Hydrogen \\
$\mathrm{CaCO}_{3}$ & Calcium Carbonate \\
$\mathrm{P}_{2} \mathrm{O}_{5}$ & Phosphorus Pentoxide \\
$\mathrm{K}_{2} \mathrm{O}$ & Potassium Oxide \\
$r$ & Correlation Coefficient \\
\hline
\end{tabular}

\section{References}

Altın M, Gokkus A \& Koc A (2011). Meadow-Pasture Management. Ministry of Agriculture and Rural Affairs General Directorate of Agricultural Production and Development Publishers, Ankara, pp. 468

Amiri F \& Saadatfar A (2009). Using the ordination method for determination of effective environmental factors on Astragalus parawinus species establishment in the semi-arid region of Iran. Asian Journal of Plant Sciences 8(1): 11-19

Anderson M J, Ellingsen K E \& McArdle B H (2006). Multivariate dispersion as a measure of beta diversity. Ecology Letters 9(6): 683-693

Brown J H (1984). On the relationship between abundance and distribution of species. American Naturalist 124(2): 255-279

Clark D B \& Mann V I (1999). Edaphic factors and landscape-scale distribution of tropical rain forest trees. The Journal of Ecology 80(8): 2662-2665

Curtis J T \& McIntosh R P (1950). The interrelations of certain analytic and synthetic phytosociological characters. Ecology 31(3): 434-455 
Escudero A, Iriondo J M \& Olano J M (2000). Factors affecting the establishment of a gypsophyte: the case of Lepidium subulatum (Brassicaceae). American Journal of Botany 87(6): 861-871

Gee G W \& Bauder J W (1986). Particle-size analysis. In: Methods of Soil Analysis. Part 1. Physical and Mineralogical Methods. $2^{\text {nd }}$ ed. (Ed. A Klute). American Society of Agronomy-Soil Science Society of America, Madison, Wisconsin, USA, pp. 383-411

Gokkus A, Koc A \& Comaklı B (1995). Meadow-Pasture Application Guide. Atatürk University Faculty of Agriculture Publishers, Erzurum, Publ. No: 142

Hill M O \& Gauch H G (1980). Detrended correspondence analysis: an improved ordination technique. Vegetatio 42(1-3): 47-58

Hoveizeh H (1997). Study of the vegetation cover and ecological characteristics in saline habitats of Hoor-e-Shadegan. Journal Research Constr 34(1): 27-31

Ispirli K, Alay F, Uzun F \& Cankaya N (2016). Impacts of livestock grazing and topography on vegetation cover and structure in natural rangelands. Turkish Journal of Agricultural Research 3(1): 14-22

Jin-Tun Z \& Oxley E R B (1994). A comparison of three methods of multivariate analysis of upland grasslands in North Wales. Journal of Vegetation Science 5(1): 71-76

Kabir M, Zafariqbal M, Farooqi Z R \& Shafiq M (2010). Vegetation pattern and soil characteristics of the polluted industrial area of Karachi. Pakistan Journal of Botany 42(1): 661-678

Kargar-Chigani H, Javadi S A, Zahedi-Amiri G, Khajeddin J \& Jafari M (2017). Vegetation composition differentiation and speciesenvironment relationships in the northern part of Isfahan Province. Iran Journal of Arid Land 9(2): 161-175

Khan W, Khan S M, Ahmad H, Ahmad Z \& Page S (2016). Vegetation mapping and multivariate approach to indicator species of a forest ecosystem: A case study from the Thandiani sub Forests Division (TsFD) in the Western Himalayas. Ecological Indicators 71: $336-351$

Khan M, Khan S M, Ilyas M, Alqarawi A A, Ahmad Z \& Abd_Allah E F (2017). Plant species and communities assessment in interaction with edaphic and topographic factors; an ecological study of the mount Eelum District Swat. Pakistan Saudi Journal of Biological Sciences 24(4): 778-786

Khan W, Khan S M, Ahmad H, Alqarawi A A, Shah G M, Hussain M \& Abdallah E F (2018). Life forms, leaf size spectra and diversity indices of plant species grown in the Thandiani forests, district Abbottabad, Khyber Pakhtunkhwa. Pakistan Saudi Journal of Biological Sciences 25(1): 94-100

Kirkpatrick J B, Green K, Bridle K L \& Venn S E (2014). Patterns of variation in Australian alpine soils and their relationships to parent material, vegetation formation, climate and topography. Catena 121: 186-194

Kitayama K (1992). An altitudinal transect study of the vegetation on Mount Kinabalu, Borneo. Vegetatio 102(2): 149-171

Koc A \& Cakal S (2004). Comparison of some rangeland canopy coverage methods. In: International Soil Congress. June 7-10, Erzurum, pp. 41-45

Kumar S (1996). Trends in structural compositional attributes of duneinterdune vegetation and their edaphic relations in the Indian desert. Vegetatio 124(1): 73-93

McCune B \& Mefford M J (1999). PC-ORD for Windows. Multivariate Analysis of Ecological Data. Version 4.14. User's Guide. Gleneden Beach, OR, USA: MjM Software

McLean E O (1982). Soil pH and lime requirement. In: Methods of Soil Analysis. Part 2. Chemical and Microbiological Properties. $2^{\text {nd }}$ ed. (Ed. A Klute). American Society of Agronomy-Soil Science Society of America, Madison, Wisconsin, USA, pp. 199-224

Mofidi M, Rashtbari M, Abbaspour H, Ebadi A, Sheidai E \& Motamedi J (2012). Impact of grazing on chemical, physical and biological properties of soils in the mountain rangelands of Sahand, Iran. The Rangeland Journal 34(3): 297-303

Nelson D W \& Sommers L E (1982). Total carbon, organic carbon, and organic matter. In: Methods of Soil Analysis. Part 2. Chemical and Microbiological Properties, pp. 539-579 
Olsen S R \& Sommers L E (1982). Phosphorus. In: Methods of Soil Analysis. Part 2. Chemical and Microbiological Properties. $2^{\text {nd }}$ ed. (Ed. A Klute). American Society of Agronomy-Soil Science Society of America, Madison, Wisconsin, USA, pp. 403-427

Partridge T R \& Wilson J B (1989). Methods for investigating vegetation/environment relations-a test using the salt marsh vegetation of Otago, New Zealand. New Zealand Journal of Botany 27: 35-47

Rahman A, Khan S M, Hussain A, Rahman I U, Iqbal Z \& Ijaz F (2016). Ecological assessment of plant communities and associated edaphic and topographic variables of the Peochar Valley District Swat of the Hindu Kush Mountains. Mountain Research and Development 36(3): 332-341

Ridolfi L, Laio F \& D'Odorico P (2008). Fertility island formation and evolution in dryland ecosystems. Ecology and Society 13(5): 439-461

Siefert A, Ravenscroft C, Althoff D, Alvarez-Yépiz J C, Carter B E, Glennon K L, Heberling M, Jo I, Pontes A, Sauer A, Willis A \& Fridley J D (2012). Scale dependence of vegetation-environment relationships: a meta-analysis of multivariate data. Journal of Vegetation Science 23(5): 942-951

Solon J, Degórski M \& Roo-Zieliska E (2007). Vegetation response to a topographical-soil gradient. Catena 71(2): 309-320

Surmen M \& Kara E (2018). Yield and quality characteristics of rangelands which have different slopes in Aydın ecological conditions. Derim 35(1): 67-72

Surmen M, Yavuz T, Surmen B, Kutbay H G, Tongel O \& Yilmaz H (2013). Evaluation of Cuminum cyminum L. invasiveness potential in grassland and pastures of Central Black Sea Region (Samsun/Turkey). Journal of Anatolian Natural Sciences 4(2): 7-13

Thomas G W (1982). Exchangeable cations. In: Methods of Soil Analysis. Part 2. Chemical and Microbiological Properties. $2^{\text {nd }}$ ed. (Ed. A Klute). American Society of Agronomy-Soil Science Society of America, Madison, Wisconsin, USA, pp. 159-165

Villers-Ruiz L, Trejo-Vázquez I \& López-Blanco J (2003). Dry vegetation in relation to the physical environment in the Baja California Peninsula, Mexico. Journal of Vegetation Science 14(4): 517-524

Zhang J T \& Dong Y (2009). Effects of grazing intensity, soil variables, and topography on vegetation diversity in the subalpine meadows of the Zhongtiao Mountains, China. The Rangeland Journal 31(1): 353-360

Zhang X, Wang M, She B \& Xiao Y (2006). Quantitative classification and ordination of forest communities in Pangquangou National Nature Reserve. Acta Ecologica Sinica 26: 754-761

Zhengchao R, Huazhong Z, Hua S \& Xiaoni L (2016). Climatic and topographical factors affecting the vegetative carbon stock of rangelands in arid and semiarid regions of China. Journal of Resources and Ecology 7(6): 418-429 